\title{
The Value of Serum Pro-Calcitonin in Diagnosis of Spontaneous Bacterial Peritonitis (SBP) and Predicting Response to Treatment
}

\author{
MAHMOUD H. ALLAM, M.D.*; AHMED A. ALSHARAWY, M.D.** and TARY A. SALMAN, M.D.* \\ The Departments of Hepatology \& Gastroenterology* and Clinical Pathology**, National Liver Institute, Menoufiya University
}

\begin{abstract}
Background: Spontaneous Bacterial Peritonitis (SBP) is a fatal complication of liver cirrhosis. Early diagnosis and appropriate management is crucial as regard patients' survival.

Aim of Study: To assess the value of serum Pro-calcitonin in diagnosis of Spontaneous Bacterial Peritonitis (SBP) and predicting its response to treatment.

Patients and Methods: Forty eight patients with ascites and suspicion of peritoneal fluid infection were enrolled. Diagnosis of SBP was confirmed by ascitic fluid analysis in 24 patients. Serum Procalcitonin was measured at time of admission for all enrolled patients and after 5 days of antibiotic treatment for those with SBP.

Results: At a cut-off of value of $0.55 \mathrm{ng} / \mathrm{mL}$, procalcitonin had the best sensitivity (100\%), specificity $(83.3 \%)$ and (99.9\%) accuracy in predicting SBP diagnosis. After 5 days of antibiotic treatment, thirteen patients (54.2\%) responded to treatment. Procalcitonin had a $(100 \%)$ sensitivity, $(87.5 \%)$ specificity and (100\%) accuracy at a cut-off value of $0.45 \mathrm{ng} / \mathrm{mL}$ in predicting response to antibiotic treatment.
\end{abstract}

Conclusion: Procalcitonin may be a valuable non-invasive marker for diagnosis and guiding antibiotic therapy for patients with SBP.

Key Words: Ascites - Liver cirrhosis - Procalcitonin - Spontaneous bacterial peritonitis.

\section{Introduction}

LIVER cirrhosis stands as the most common cause of ascites followed by malignancy, heart failure, tuberculosis, pancreatic disease, or other miscellaneous causes [1]. About $50 \%$ of patients with liver cirrhosis can develop ascites over 10 years with up to $50 \%$ mortality over 2 years specially with developing complications such as peritoneal fluid infections [2,3].

Correspondence to: Dr. Mahmoud H. Allam, E-Mail: drmahmoudallam77@ @mail.com
Spontaneous Bacterial Peritonitis (SBP) is the most common bacterial infection of ascites in patients with liver cirrhosis [4]. Mortality is very high in patients with SBP, it may be more than $90 \%$ of diagnosed patients. However, this fatality reduced to less than $20 \%$ when early diagnosis and treatment is established [5]

The gold standard method for the diagnosis of SBP is a Polymorphonuclear Cell (PMN) count of $>250$ cells $/ \mathrm{mm}^{3}$ in the ascitic fluid, regardless of bacterial isolation [6]. However, the diagnosis of SBP is not always easy because SBP is sometimes asymptomatic, and a delay in the diagnosis due to difficulty of paracentesis procedure, low ascitic fluid culture positivity (approximately 30\%), delay in culture results and iatrogenic SBP risk after diagnostic paracentesis often lead to fatal complications such as sepsis or multiple organ failure $[7,8]$.

Therefore, the need for novel biomarkers for early diagnosis of SBP and early prediction of response to the first treatment are desirable because nonresponse to the first treatment is a predictor of increased mortality with SBP [9].

Pro-calcitonin, a pro-peptide of calcitonin with a long half-life of $25-30 \mathrm{~h}$ which is significantly increased with systemic responses to the infections, has been raised as a novel inflammation marker for bacterial infections $[\mathbf{1 0 , 1 1 ]}$.

Pro-calcitonin is undetectable in the serum of healthy humans with values $<0.5 \mathrm{ng} / \mathrm{mL}$ [12], so, it seems to be superior to C-Reactive Protein (CRP)

\section{Abbreviations:}

SBP : Spontaneous Bacterial Peritonitis.

PCT : Procalcitonin.

CRP : C-Reactive Protein. 
in discriminating infectious from other inflammatory diseases such as acute pancreatitis, cardiogenic shock and acute transplant rejection [13]

Rapid detection of serum pro-calcitonin can be made within 2 hours of development of symptoms. Also, being non-invasive simple bedside test with moderate cost added more advantage to serum procalcitonin over the traditional cell count for the diagnosis of SBP, especially in the absence of other infections [11].

\section{Patients and Methods}

This prospective observational study was conducted on forty-eight patients with liver cirrhosis and ascites. Patients recruited from Emergency Unit of the Hepatology and Gastroenterology Department, National Liver Institute (NLI), Menoufiya University, Egypt at period between June 2018 and February 2019.

The study started after approval by the Ethical $\&$ Scientific Committee of NLI and a written consent filled by all patients included in this study.

Patients with stigmata of liver cirrhosis and ascites presented with suspicious symptoms of ascitic fluid infection (e.g. abdominal pain, tenderness, fever, and diarrhea) were selected for this study.

Patients with hepatocellular carcinoma \& those with Ascites due to other causes (cardiac, pancreatic etc.) were excluded. The presence of an ongoing infection other than SBP or history receiving antibiotic or immunosuppressive therapy within the last month before inclusion were other reasons for exclusion.

Immediately after hospital admission, full history taking and physical examination were done for all patients. Routine abdominal ultrasound examination was done for all patients and dynamic Computed Tomography (CT) scan was requested on detecting any suspicious liver focal lesion on $\mathrm{U} / \mathrm{S}$ examination.

A blood sample was withdrawn for baseline laboratory assessment including: Complete Blood Count (CBC), Liver tests (Alanine Aminotransferase (ALT), Aspartate Aminotransferase (AST), serum Bilirubin, serum Albumin, Prothrombin time $\&$ INR and total protein levels), renal function tests (urea and creatinine levels), serum Alfafetoprotein (AFP) and C-Reactive Protein (CRP).
Then, Child-Pugh and MELD scores were calculated for these patients on admission according to their known formulae.

A bedside diagnostic paracentesis under complete sterile condition was done with aspiration of about $20 \mathrm{ml}$ of ascitic fluid. The aspirate was subjected to the following tests:

1- Automated total counting of the leucocytes of the aspirate and if the count was higher than 1000 cell $/ \mathrm{mm}^{3}$, a film from the sample was spread and stained by hematoxilin and eosin stains for manual differential counting of white blood cells.

2- Chemical analysis of the ascitic fluid sample including measurement of total proteins, albumin, glucose and Lactate Dehydrogenase (LDH) levels. Serum-Ascites Albumin Gradient (SAAG) was calculated.

3- Ascitic fluid aspirates were cultured and on bacterial growth, antimicrobial sensitivity was studied.

Serum pro-calcitonin level was measured for all studied patients using Electrochemiluminescence Immunoassay (ECLIA) methods. These serum samples were withdrawn at the same time of ascitic fluid aspiration.

\section{Patients were then stratified into two groups:}

1- Group I: (24) patients with diagnosis of SBP (Total Leucocytic Count (TLC) >500 and/or polymorphnuclear count $(\mathrm{PMN})>250 \mathrm{~mm}^{3}$ ).

2- Group II: (24) patients without diagnosis of SBP (Total Leucocytic Count (TLC) <500).

Patients of group (I) started empirical antibiotic regimen immediately after admission using $3 \mathrm{rd}$ generation of cephalosporin (Cefotaxime $2 \mathrm{gm}$. I.V/12 hours) as the first choice $[\mathbf{1 4 , 1 5 ]}$

Quinolones were used as the second choice (Ciprofloxacin 500mg I.V/12 hours), if TLC in ascites didn't drop more than $75 \%$ of its baseline after 72 hours after starting Cephalosporin.

The patients were shifted to the antibiotic recommended by sensitivity test of the culture of the ascitic sample when the results were available.

On the fifth day of admission, another blood sample was withdrawn, and the same laboratory tests done at baseline were repeated including serum pro-calcitonin level. In addition, an ascitic 
fluid sample was aspirated and response to treatment was assessed by counting TLC count.

\section{Patients were further subdivided on two subgroups:}

Subgroup Ia: Included patients who responded to antibiotic therapy determined by drop of TLC count in ascetic fluid to less than 250 cells $/ \mathrm{mm}^{3}$.

Subgroup Ib: Included patients who didn't respond to antibiotic therapy.

\section{Statistical analysis:}

Patients' data were subjected to statistical analysis including Chi-square test for qualitativevariables. While, student $t$-test and Mann Whitney test were used to compare mean and standard deviation of the two sets of quantitative variables.

Comparing correlation between two continuous variables was done by correlation analysis. In addition, ROC curve (Receiver Operating Characteristic curve) was blotted to detect cut off values for different factors predicting diagnosis of SBP and response to treatment. Sensitivity, specificity and accuracy of these cut off values were then studied.

\section{Results}

Group I, (patients with SBP group) included 17 males and 7 females $(70.8 \% \& 29.2 \%$ respectively), with mean age $53.25 \pm 10.06$ years. Group II, (those without SBP) included 10 males and 14 females $(41.7 \%$ \& $58.3 \%$ respectively) with mean age $50.1 \pm 10.1$ years. SBP diagnosis was more in males than females while patients' age had no statistical significance with SBP occurrence, Table (1).

On comparing initial laboratory assessment results between both study groups, serum albumin for patients of group I were lower than those of group II \& this was of statistical significance with diagnosis of SBP, Table (1).

The same was noticed as regard serum bilirubin, INR, blood total leucocyte count and calculated MELD and Child's scores for group I patients that were higher than those of group II patients and they were confiding with SBP diagnosis, Table (1).

Kidney function tests were also different between both study groups. Serum creatinine, blood urea and serum potassium levels were higher, and serum sodium was lower in group I patients than those of the other group, Table (1).
Also, patients with SBP had higher levels of serum pro-calcitonin and CRP than those without SBP. Serum pro-calcitonin and CRP measured on admission were statistically significant with diagnosis of SBP, Table (1).

Table (1): Demographics \& laboratory data of studied patients on admission $(\mathrm{n}=48)$.

\begin{tabular}{|c|c|c|c|}
\hline Variables & $\begin{array}{c}\text { Group I } \\
\text { (with SBP) } \\
\mathrm{N}=24(\mathrm{M} \pm \mathrm{SD})\end{array}$ & $\begin{array}{c}\text { Group II } \\
\text { (without SBP) } \\
\mathrm{N}=24(\mathrm{M} \pm \mathrm{SD})\end{array}$ & $p$ \\
\hline Age (years) & $53.2 \pm 10$ & $50.1 \pm 10.11$ & $>0.05$ \\
\hline \multicolumn{4}{|l|}{ Sex: } \\
\hline Female & $7 \quad(29.2)$ & $14(58.3)$ & $<0.05$ \\
\hline Male & $17(70.8)$ & $10(41.7)$ & \\
\hline $\mathrm{Hb}(\mathrm{g} / \mathrm{dL})$ & $9.9 \pm 1.5$ & $9.6 \pm 0.3$ & $>0.05$ \\
\hline WBCs X $10^{3} / \mu \mathrm{L}$ & $3.6 \pm 0.7$ & $2.8 \pm 0.5$ & $<0.01$ \\
\hline Platelets X $10^{3} / \mu \mathrm{L}$ & $80.9 \pm 52.6$ & $68.8 \pm 24.3$ & $>0.05$ \\
\hline Total Bilirubin (mg/dL) & $7.4 \pm 6.2$ & $2.9 \pm 1.9$ & $<0.01$ \\
\hline Albumin (g/dL) & $1.8 \pm 0.3$ & $2.1 \pm 0.4$ & $<0.05$ \\
\hline $\operatorname{AST}(\mathrm{U} / \mathrm{L})$ & $75 \pm 42.5$ & $54.8 \pm 35.4$ & $>0.05$ \\
\hline ALT (U/L) & $35.3 \pm 22$ & $27.5 \pm 8$ & $>0.05$ \\
\hline $\operatorname{ALP}(\mathrm{U} / \mathrm{L})$ & $104.2 \pm 50$ & $113.9 \pm 53.3$ & $>0.05$ \\
\hline GGT (U/L) & $35.7 \pm 30$ & $25.3 \pm 15.5$ & $>0.05$ \\
\hline INR & $2.1 \pm 0.6$ & $1.4 \pm 0.1$ & $<0.01$ \\
\hline CTP score & $11.6 \pm 1.4$ & $10.2 \pm 1.5$ & $<0.01$ \\
\hline MELD score & $26.4 \pm 7.4$ & $14.1 \pm 2.7$ & $<0.01$ \\
\hline Urea (mg/dL) & $113.7 \pm 76.3$ & $48.3 \pm 28.3$ & $<0.01$ \\
\hline Creatinine (mg/dL) & $2.1 \pm 1.5$ & $0.7 \pm 0.3$ & $<0.01$ \\
\hline $\mathrm{Na}(\mathrm{mmol} / \mathrm{L})$ & $123.2 \pm 5.4$ & $127.7 \pm 4.6$ & $<0.05$ \\
\hline $\mathrm{K}(\mathrm{mmol} / \mathrm{L})$ & $4.5 \pm 0.7$ & $4 \pm 0.4$ & $<0.05$ \\
\hline CRP (mg/L) & $36.9 \pm 20.3$ & $26.3 \pm 19.8$ & $<0.01$ \\
\hline Pro-calcitonin (ng/mL) & $4.6 \pm 2.3$ & $0.3 \pm 0.1$ & $<0.01$ \\
\hline
\end{tabular}

Ascites characteristics:

Table (2): Characteristics of ascitic fluid of studied patients on admission $(\mathrm{n}=48)$.

\begin{tabular}{|c|c|c|c|}
\hline Variables & $\begin{array}{c}\text { Group I } \\
\text { (with SBP) } \\
\mathrm{N}=24(\mathrm{M} \pm \mathrm{SD})\end{array}$ & $\begin{array}{c}\text { Group II } \\
\text { (without SBP) } \\
\mathrm{N}=24(\mathrm{M} \pm \mathrm{SD})\end{array}$ & $p$ \\
\hline TLC count (cell//mm $\left.{ }^{3}\right)$ & $9958.3 \pm 1184.17$ & $354.1 \pm 50.8$ & $<0.01$ \\
\hline LDH (U/L) & $222.8 \pm 147.2$ & $100.2 \pm 33.2$ & $<0.01$ \\
\hline Glucose (mg/L) & $140.6 \pm 83.3$ & $121.4 \pm 20.2$ & $>0.05$ \\
\hline Total protein $(\mathrm{g} / \mathrm{L})$ & $1.1 \pm 0.5$ & $1 \pm 0.1$ & $>0.05$ \\
\hline Albumin (g/L) & $0.4 \pm 0.2$ & $0.2 \pm 0.09$ & $<0.01$ \\
\hline \multicolumn{4}{|l|}{ Amount of ascites: } \\
\hline Minimal & $1 \quad(4.2 \%)$ & $7 \quad(29.2 \%)$ & $<0.01$ \\
\hline Mild & $4 \quad(16.7 \%)$ & $10(41.7 \%)$ & \\
\hline Moderate & $15(62.5 \%)$ & $7 \quad(29.2 \%)$ & \\
\hline Marked & $4 \quad(16.7 \%)$ & 0 & \\
\hline SAAG & $1.4 \pm 0.2$ & $1.8 \pm 0.4$ & $<0.01$ \\
\hline
\end{tabular}

Ascites amount estimated initially by ultrasound examination was quite different between both groups. Those who developed SBP (group I) had more ascites volumes than those of group II, Table (2). 
Chemical and cytological analysis of a sample of ascitic fluid was the cornerstone for diagnosis of SBP. Therefore, total leucocytic count and LDH were higher, while albumin level was lower for those with SBP. However, total proteins and glucose levels were not significantly correlating with SBP development, Table (2).

Culture of the ascitic fluid aspirated on admission revealed that only five patients $(20.8 \%)$ of group (I) had growing organisms on their cultures, while the remaining 19 patients $(79.2 \%)$ didn't have bacterial growth on their cultures. Klebsiella was isolated for four patients, while E. Coli was isolated for a single patient.

For group II patients: The 24 patients $(100 \%)$ had no bacterial growth on their cultures of ascitic fluid.

After completion of 5 days of antibiotic therapy, group I patients were re-evaluated \& a new ascitic fluid sample was withdrawn for cytological and chemical analysis, Table (3). Patients were further subdivided. Subgroup Ia included those who responded to treatment of SBP (13 patients, 54.2\%), while subgroup Ib included those who didn't respond (11 patients, $45.8 \%$ ), Table (3).

Table (3): Demographics \& laboratory data of patients with SBP after 5 days of treatment $(n=24)$.

\begin{tabular}{|c|c|c|c|}
\hline Variables & $\begin{array}{c}\text { Group Ia } \\
\text { (responded to } \\
\text { treatment) } \\
\mathrm{N}=13(\mathrm{M} \pm \mathrm{SD})\end{array}$ & $\begin{array}{c}\text { Group } \mathrm{Ib} \\
\text { (no responded } \\
\text { to treatment) } \\
\mathrm{N}=11(\mathrm{M} \pm \mathrm{SD})\end{array}$ & $p$ \\
\hline Age (years) & $55.3 \pm 7.9$ & $52.1 \pm 11.05$ & $>0.05$ \\
\hline \multicolumn{4}{|l|}{ Sex: } \\
\hline Female & $4(30.7 \%)$ & $4(36.4 \%)$ & $>0.05$ \\
\hline Male & $9(69.3 \%)$ & $7(63.6 \%)$ & \\
\hline $\mathrm{Hb}(\mathrm{g} / \mathrm{dL})$ & $9.1 \pm 1.8$ & $10.3 \pm 1.2$ & $>0.05$ \\
\hline WBCs X $10^{3} / \mu \mathrm{L}$ & $8.3 \pm 4.4$ & $8.4 \pm 3.3$ & $>0.05$ \\
\hline Platelets X $10^{3} / \mu \mathrm{L}$ & $91.6 \pm 47.0$ & $75.6 \pm 55.9$ & $>0.05$ \\
\hline Total Bilirubin (mg/dL) & $4.7 \pm 2.3$ & $7.7 \pm 1.4$ & $>0.05$ \\
\hline Albumin (g/dL) & $1.9 \pm 0.2$ & $1.8 \pm 0.3$ & $>0.05$ \\
\hline $\operatorname{AST}(\mathrm{U} / \mathrm{L})$ & $70.1 \pm 34.7$ & $77.5 \pm 46.7$ & $>0.05$ \\
\hline ALT (U/L) & $31.5 \pm 13.3$ & $37.3 \pm 25.4$ & $>0.05$ \\
\hline $\operatorname{ALP}(\mathrm{U} / \mathrm{L})$ & $102.5 \pm 61.2$ & $105.1 \pm 45.5$ & $>0.05$ \\
\hline GGT (U/L) & $31.2 \pm 38.4$ & $38.0 \pm 26.0$ & $>0.05$ \\
\hline INR & $1.8 \pm 0.4$ & $1.9 \pm 0.5$ & $>0.05$ \\
\hline CTP score & $10.9 \pm 1.4$ & $11.5 \pm 0.9$ & $>0.05$ \\
\hline MELD score & $23.4 \pm 5.3$ & $24.8 \pm 6.1$ & $>0.05$ \\
\hline Urea (mg/dL) & $106.1 \pm 71.4$ & $117.5 \pm 80.6$ & $>0.05$ \\
\hline Creatinine (mg/dL) & $2.1 \pm 1.3$ & $2.1 \pm 1.6$ & $>0.05$ \\
\hline $\mathrm{Na}(\mathrm{mmol} / \mathrm{L})$ & $124.1 \pm 5.8$ & $122.8 \pm 5.3$ & $>0.05$ \\
\hline $\mathrm{K}(\mathrm{mmol} / \mathrm{L})$ & $4.4 \pm 0.6$ & $4.5 \pm 0.8$ & $>0.05$ \\
\hline CRP (mg/L) & $10.4 \pm 6.2$ & $35.9 \pm 26.6$ & $<0.01$ \\
\hline Procalcitonin (ng/mL) & $0.3 \pm 08$ & $2.1 \pm 2.0$ & $<0.01$ \\
\hline
\end{tabular}

Serum pro-calcitonin and CRP levels were statistically significant with achieving response to treatment while no other parameters had significant relation with response, Tables $(3,4)$.

Table (4): Characteristics of ascitic fluid of patients with SBP after 5 days of treatment $(n=24)$.

\begin{tabular}{llll}
\hline Variables & $\begin{array}{c}\text { Group Ia } \\
\mathrm{N}=13(\mathrm{M} \pm \mathrm{SD})\end{array}$ & $\begin{array}{c}\text { Group Ib } \\
\mathrm{N}=11(\mathrm{M} \pm \mathrm{SD})\end{array}$ & $p$ \\
\hline TLC & $362.5 \pm 51.7$ & $4256.2 \pm 5347.2$ & $<0.01$ \\
LDH (U/L) & $172.7 \pm 99.2$ & $247.9 \pm 163.2$ & $>0.05$ \\
Glucose (mg/L) & $124.1 \pm 5.8$ & $147.7 \pm 5.8$ & $>0.05$ \\
Total protein (g/L) & $0.87 \pm 0.39$ & $1.2 \pm 0.5$ & $>0.05$ \\
Albumin (g/L) & $0.3 \pm 0.1$ & $0.4 \pm 0.2$ & $>0.05$ \\
Amount of ascites: & & & $>0.01$ \\
$\quad$ Minimal & $1(7.6 \%)$ & $1(9 \%)$ & \\
$\quad$ Mild & $5(38.4 \%)$ & $5(45.4 \%)$ & $>0.05$ \\
$\quad$ Moderate & $4(30.7 \%)$ & $3(27.2 \%)$ & \\
$\quad$ Marked & $3(23 \%)$ & $2(18.1 \%)$ & \\
SAAG & $1.4 \pm 0.2$ & $1.4 \pm 0.2$ & \\
\hline
\end{tabular}

The ability of serum pro-calcitonin and CRP to predict diagnosis of SBP was compared to TLC count in ascites which is considered the gold standard for diagnosis. Receiver operating curves were blotted, Table (5) and Fig. (1).

Table (5): Comparison between Procalcitonin, CRP and ascites TLC count in predicting SBP diagnosis.

\begin{tabular}{lcccccc}
\hline & $\begin{array}{c}\text { Cut } \\
\text { level }\end{array}$ & AUC & $\begin{array}{c}\text { Sensi- } \\
\text { tivity }\end{array}$ & $\begin{array}{c}\text { Speci- } \\
\text { ficity }\end{array}$ & Accuracy & $\begin{array}{c}p \text { - } \\
\text { value }\end{array}$ \\
\hline Procalcitonin & 0.55 & 0.997 & $100 \%$ & $83.3 \%$ & $99.9 \%$ & $<0.01$ \\
CRP & 23.5 & 0.72 & $75.0 \%$ & $75.0 \%$ & $71.6 \%$ & $<0.01$ \\
TLC in ascites & 7.3 & 0.79 & $75.0 \%$ & $70.9 \%$ & $81.2 \%$ & $<0.01$ \\
\hline
\end{tabular}

The same was done as regard ability of serum procalcitonin, CRP in predicting the response to treatment of SBP on comparison with ascitic fluid TLC. Serum procalcitonin had the highest sensitivity, specificity and accuracy in predicting response to treatment, Table (6) and Fig. (1).

Table (6): Comparison between Procalcitonin, CRP and ascites TLC count in predicting response to treatment of SBP.

\begin{tabular}{lcccccc}
\hline & $\begin{array}{c}\text { Cut } \\
\text { level }\end{array}$ & AUC & $\begin{array}{c}\text { Sensi- } \\
\text { tivity }\end{array}$ & $\begin{array}{c}\text { Speci- } \\
\text { ficity }\end{array}$ & Accuracy & $\begin{array}{c}p \text { - } \\
\text { value }\end{array}$ \\
\hline Procalcitonin & 0.45 & 1 & $100 \%$ & $87.5 \%$ & $100.0 \%$ & $<0.01$ \\
CRP & 10.4 & 0.573 & 76.9 & 30 & 30 & $>0.05$ \\
Ascites TLC & 5.55 & 0.688 & 76.9 & 40 & 40 & $>0.05$ \\
\hline
\end{tabular}




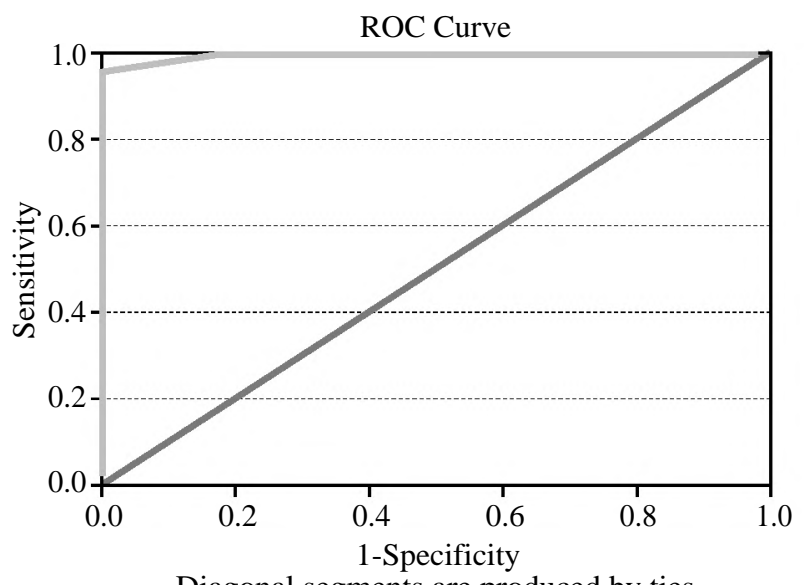

Diagonal segments are produced by ties ROC of procalcitonin vs. diagnosis of SBP

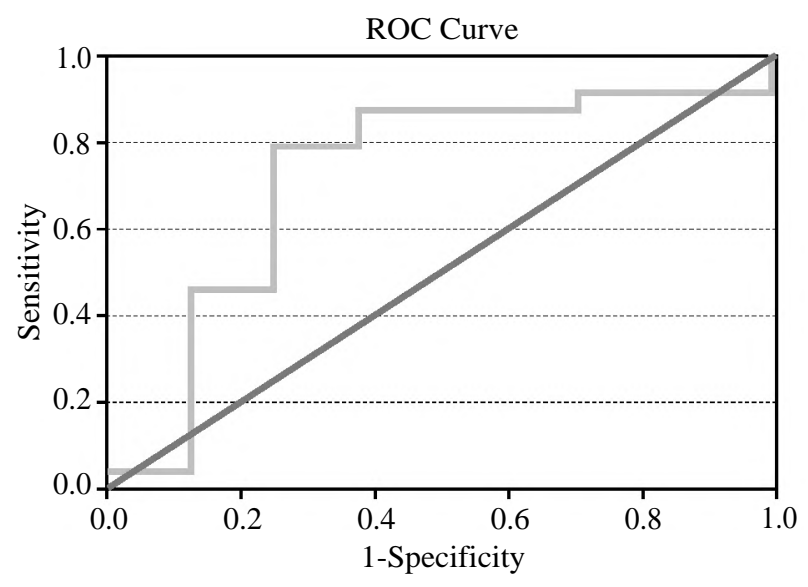

ROC of CRP vs. diagnosis of SBP

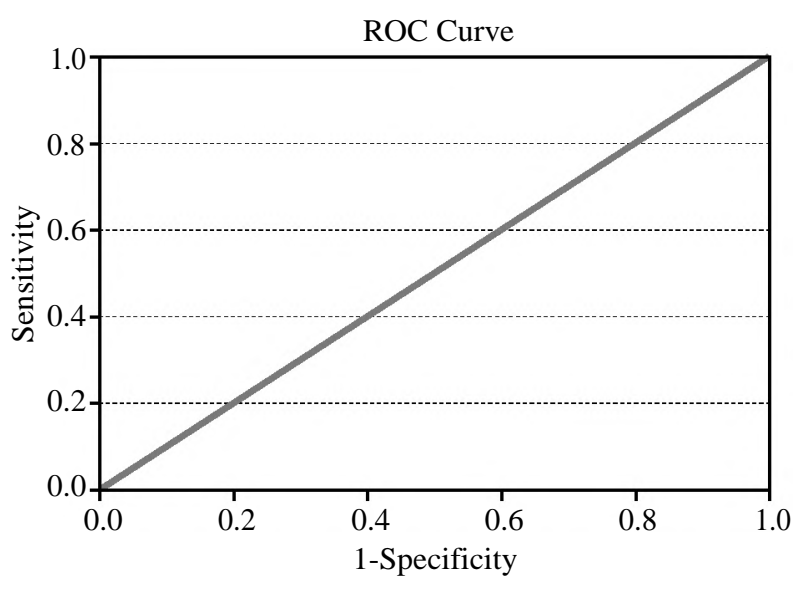

ROC of procalcitonin vs. response to treatment

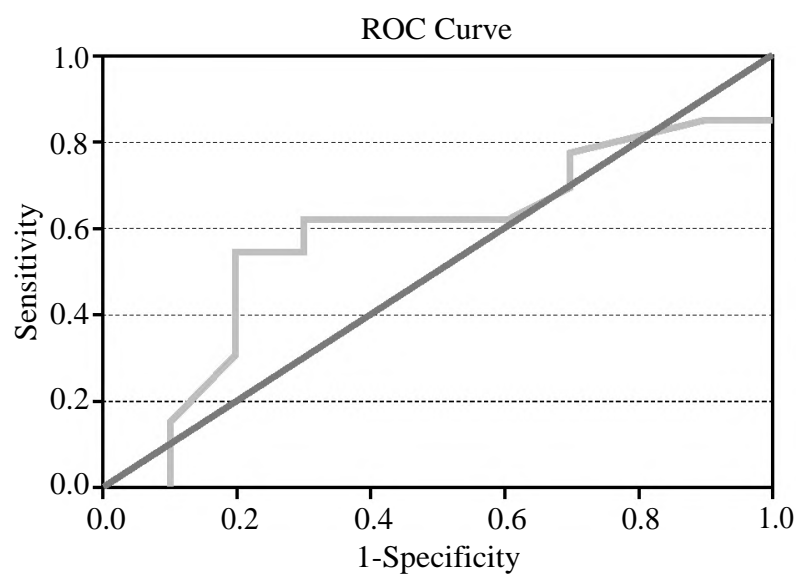

ROC of CRP vs. response to treatment

Fig. (1): ROC curves of procalcitonin and CRP for predicting diagnosis of SBP and response to treatment.

\section{Discussion}

Spontaneous Bacterial Peritonitis (SBP) is one of the most serious complications of liver cirrhosis which is associated with increased risk of morbidity and mortality. Appropriate diagnosis and prompt administration of therapy are the mainstays of the successful management.

Ascitic fluid aspiration for counting of total leucocytes count and culture of the sample are still the cornerstone for diagnosis of SBP. Measurement of markers of inflammation may be useful. But, these markers are indicative, but none of them had been considered diagnostic for SBP [12].

In terms of the value of procalcitonin (PCT) in predicting infection, this study was conducted on 48 patients with SBP. Procalcitonin levels were higher in patients with SBP than in those without SBP $(4.6 \pm 6.3 \mathrm{ng} / \mathrm{mL}$ vs. $0.3 \pm 0.1 \mathrm{ng} / \mathrm{mL})$. This was also the same for serum CRP levels and WBC count which were higher in patients with SBP, Table (1).
This was similar to findings of other studies by Viallon et al. [13], Lippi et al. [16], Cai et al. [17] and Yang et al. [18], who stated that procalcitonin levels were significantly higher in patients with infected ascites than in those with sterile ascites.

But, this was in contrast to other studies by Spahr et al. [19] and Schwabl et al. [20], who found no difference between both groups.

Additionally, PCT was better than CRP and WBC count in predicting SBP diagnosis in our cohort with better sensitivity and specificity. At a cutoff of value of $0.55 \mathrm{ng} / \mathrm{mL}$, it had the best sensitivity (100\%), specificity (83.3\%) and (99.9\%) accuracy, Table (5).

Similar studies conducted on patients with peritoneal fluid infection revealed different results. In a study by Cekin et al. [12], it was demonstrated that for the SBP group, the cut-off value for procalcitonin level was $0.61 \mathrm{ng} / \mathrm{mL}$ with a sensitivity of $100 \%$ and a specificity of $92 \%$. A serum procalcitonin level of $<0.61 \mathrm{ng} / \mathrm{mL}$ (AUC: $0.981,95 \%$ 
CI: $0.000-1.000, p<0.001)$ was determined to accurately rule out the diagnosis of ascites infection. In another study, the serum levels of procalcitonin were reported to be one of the best markers for the diagnosis of SBP, with a cut-off value of 0.75 $\mathrm{ng} / \mathrm{mL}$, sensitivity of $95 \%$, and specificity of $98 \%$ [13] .

In a systemic review and meta-analysis in 2014, Yang et al., [18] evaluated 18 studies and their results indicated that procalcitonin determination is a relatively sensitive and specific test for the diagnosis of bacterial peritonitis.

This was in contrast with another study by Spahr et al., [19], who concluded that procalcitonin levels were inaccurate in these patients; however, this study was limited by a small sample size.

Schwabl et al., [20] could not find a correlation between the parameters of mortality risk in patients with SBP and procalcitonin levels; however, only the first-day procalcitonin levels were measured, and procalcitonin response to antibiotic treatment was not measured.

In the current study, all SBP patients were treated with third generation cephalosporin in the dose of $2 \mathrm{~g} / 12$ hours daily. Cefotaxime, a thirdgeneration cephalosporin, has been extensively investigated in patients with SBP because it covers most causative organisms and because of its high ascitic fluid concentrations during therapy [21]. A dose of $4 \mathrm{~g} /$ day is as effective as a dose of $8 \mathrm{~g} /$ day $[14,15,22]$.

Inoculation of ascitic fluid in blood culture bottles often displays Escherichia coli and Streptococcus species [23]. But at the current study the most prominent organism was Klebsiella than E coli, may be due to the few number of positive ascitic culture fluid cultures and repeated use of antibiotics for these patients before admission.

After 5 days of antibiotic therapy, another ascitic sample was withdrawn and WBC was retested; 13 patients out of $24(54.2 \%)$ responded to antibiotic treatment while 11 patients $(45.8 \%)$ didn't respond. In contrast to Badawy et al., study [24] who had improvement in $81 \%$ of his cohort on the same antibiotic regimen. This could be attributed to the different nosocomial environment and bacterial resistance.

In the present study as well as that of Badawy et al., there was no statistical significant difference between patients responding to the above mentioned regimen as regard age, gender, amount of ascitic fluid and degree of liver impairment. This could be attributed to the organism and its sensitivity to the antibiotic used.

Blind and repeated prescriptions of antibiotics may lead to the evolution of secondary infection and emergence of drug resistance [25]. So, serum PCT level measurement may be used the guidance of antibiotic therapy [26]

In the current study, serum procalcitonin measured after 5 days of antibiotic therapy had significant value in predicting response to treatment. At a cut-off value of $0.45 \mathrm{ng} / \mathrm{mL}$, it had the best sensitivity (100\%), specificity (87.5\%) and (100\%) accuracy. This was better than CRP and white cells count in blood, Table (6).

Lavrentieva et al., reported that PCT guided algorithm for antibiotic therapy may contribute to the reduction of antibiotic exposure in burn Intensive Care Unit [27]. Kip and colleagues assessed the cost effectiveness of PCT-based algorithm which helped to reduce the length of hospital stay, number of blood cultures and the duration of antibiotic therapy [28] . Nobre et al., concluded that antibiotic treatment based on PCT monitoring is a sensitive way of antibiotic usage in ICU patient with severe sepsis and septic shock [29].

In contrast, other studies concluded that PCT guidance of antibiotic therapy could not make better change in the mortality rate, but there was definitely a valuable effect on the duration of antimicrobial treatment $[\mathbf{3 0 , 3 1}]$

\section{Conclusion:}

Serum pro-calcitonin is simple and noninvasive test which can predict diagnosis of Spontaneous bacterial peritonitis and its response to treatment by antibiotics.

\section{References}

1- European Association for the Study of the Liver (EASL): Clinical practice guidelines on the management of ascites, spontaneous bacterial peritonitis, and hepatorenal syndrome in cirrhosis. J. Hepatol., 53 (3): 397-417, 2010.

2- GINES P., ARROYO V., QUINTERO E., PLANAS R., BORY F., CABRERA J., RIMOLA A., et al.: Comparison of paracentesis and diuretics in the treatment of cirrhotics with tense ascites: Results of a randomized study. Gastroenterology, 93: 234-41, 1987.

3- LLACH J., GINES P., ARROYO V., RIMOLA A., TITO L., BADALAMENTI S., JIMENEZ W., et al.: Prognostic value of arterial pressure, endogenous vasoactive systems, and renal function in cirrhotic patients admitted to the hospital for the treatment of ascites. Gastroetnerology, 94: 482-7, 1988. 
4- WONG F., BERNARDI M., BALK R., CHRISTMAN B., MOREAU R., GARCIA-TSAO G., et al.: Sepsis in cirrhosis: Report on the 7 th meeting of the International Ascites Club. Gut., 54: 718-25, 2005.

5- TANDON P. and GARCIA-TSAO G.: Bacterial infections, sepsis, and multi-organ failure in cirrhosis. Semin Liver Dis., 28: 26-42, 2008.

6- DEVER J.B. and SHEIKH M.Y.: Review article: Spontaneous bacterial peritonitis: Bacteriology, diagnosis, treatment, risk factors and prevention. Aliment. Pharmacol. Ther., 41: 1116-31, 2015.

7- KARVELLAS C.J., ABRALDES J.G., ARABI Y.M. and KUMAR A.: Appropriate and timely antimicrobial therapy in cirrhotic patients with spontaneous bacterial peritonitisassociated septic shock: A retrospective cohort study. Aliment. Pharmacol. Ther., 41: 747-57, 2015.

8- HOEFS J.C., CANAWATI H.N., SAPICO F.L., HOPKINS R.R., WEINER J. and MONTGOMERIE J.Z.: Spontaneous bacterial peritonitis. Hepatology, 2: 399-407, 1982.

9- PIANO S., FASOLATO S., SALINAS F., ROMANO A., TONON M., et al.: The empirical antibiotic treatment of nosocomial spontaneous bacterial peritonitis: Results of a randomized, controlled clinical trial. Hepatology, 63: 1299-309, 2016.

10- DANDONA P., NIX D., WILSON M.F., et al.: Procalcitonin increase after endotoxin injection in normal subjects. J. Clin. Endocrinol. Metab., 79 (6): 1605-1068, 1994.

11- VIALLON A., ZENI F., POUZET V., et al.: Serum and ascitic procalcitonin levels in cirrhotic patients with spontaneous bacterial peritonitis: Diagnostic value and relationship to pro-inflammatory cytokines. Intensive Care Med., 26: 1082-8, 2000

12- CEKIN Y., CEKIN A.H., DUMAN A., YILMAZ U., YESIL B. and YOLCULAR B.O.: The role of serum procalcitonin levels in predicting ascitic fluid infection in hospitalized cirrhotic and non-cirrhotic patients. Int. J. Med. Sci., 10: 1367-74, 2013.

13- VIALLON A., ZENI F., POUZET V., et al.: Serum and ascitic procalcitonin levels in cirrhotic patients with spontaneous bacterial peritonitis: Diagnostic value and relationship to pro-inflammatory cytokines. Intensive Care Med., 26: 1082-8, 2000.

14- RIMOLA A., SALMERÓN J.M., CLEMENTE G., RODRIGO L., OBRADOR A., MIRANDA M.L., GUARNER C., PLANAS R., SOLÁ R. and VARGAS V.: Two different dosages of cefotaxime in the treatment of spontaneous bacterial peritonitis in cirrhosis: Results of a prospective, randomized, multicenter study. Hepatology, Mar., 21 (3): 674-9, 1995.

15- GHASSEMI S. and GARCIA-TSAO G.: Prevention and treatment of infections in patients with liver cirrhosis. Best Pract. Res. Clin. Gastroenterol., 21 (1): 77-93, 2007.

16- LIPPI G., DANESE E., CERVELLIN G. and MONTAGNANA M.: Laboratory diagnostics of spontaneous bacterial peritonitis. Clin. Chim. Acta., 430: 164-70, 2014.

17- CAI Z.H., FAN C.L., ZHENG J.F., et al.: Measurement of serum procalcitonin levels for the early diagnosis of spontaneous bacterial peritonitis in patients with decompensated liver cirrhosis. BMC Infect Dis., 15: 55, 2015.

18- YANG S.K., XIAO L., ZHANG H., et al.: Significance of serum procalcitonin as biomarker for detection of bacterial peritonitis: A systematic review and metaanalysis. BMC Infect. Dis., 14: 452, 2014.

19- SPAHR L., MORARD I., HADENGUE A., VADAS L. and PUGIN J.: Procalcitonin is not an accurate marker of spontaneous bacterial peritonitis in patients with cirrhosis. Hepato-gastroenterology, 48: 502-5, 2001.

20- SCHWABL P., BUCSICS T., SOUCEK K., et al.: Risk factors for development of spontaneous bacterial peritonitis and subsequent mortality in cirrhotic patients with ascites. Liver Int., 35: 2121-8, 2015.

21- RICART E., SORIANO G., NOVELLA M.T., ORTIZ J., SÀBAT M., KOLLE L., et al.: Amoxicillin-clavulanic acid versus cefotaxime in the therapy of bacterial infections incirrhotic patients. J. Hepatol., 32: 596-602, 2000.

22- RIMOLA A., BORY F., TERES J., PÉREZ-AYUSO R.M., ARROYO V. and RODÉS J.: Oral, non-absorbable antibiotics prevent infection in cirrhotics with gastrointestinal hemorrhage. Hepatology, 5: 463-7, 1985.

23- GARCIA-TSAO G.: Current management of the complications of cirrhosis and portal hypertension: Variceal hemorrhage, ascites, and spontaneous bacterial peritonitis. Gastroenterology, 120: 726-48, 2001.

24- AHMED ABOUELKHAIR BADAWY, TARIK IBRAHIM ZAHER, SAMAR MAHMOUD SHARAF, MOHAMED HASSAN EMARA, NOHA ELSAID SHAHEEN, and TALAAT FATHY ALY: Effect of alternative antibiotics in treatment of cefotaxime resistant spontaneous bacterial peritonitis World J. Gastroenterol., Feb. 28; 19 (8): 12717, 2013.

25- LARSON E.: Community factors in the development of antibiotic resistance. Annu. Rev. Public Health, 28: 43547, 2007.

26- CHIROUZE C., SCHUHMACHER H., RABAUD C., GIL H., KHAYAT N., ESTAVOYER J.M., MAY T. and HOEN B.: Low-serum procalcitonin level accuracy predicts the absence of bacteraemia in adult patients with acute fever. Clin. Infect. Dis., 35: 156-61, 2002.

27- LAVRENTIEVA A., KONTOU P., SOULOUNTSI V., KIOUMIS J., CHRYSOU O. and BITZANI M.: Implementation of a procalcitonin-guided algorithm for antibiotic therapy in the burn Intensive Care Unit. Ann. Burns Fire Disasters, 28 (3): 163-70, 2015.

28- KIP M.M., KUSTERS R., IJZERMAN J. and STEUTEN M.A.: PCT algorithm for discontinuation of antibiotic therapy is a cost-effective way to reduce antibiotic exposure in adult intensive care patients with sepsis. J. Med. Econ., 18 (11): 944-53, 2015.

29- NOBRE V., HARBARTH S., GRAF J.D., ROHNER P. and JEROME P.: Use of procalcitonin to shorten antibiotic treatment duration in septic patients. Am. J. Resp. Crit. Care Med., 177: 498-505, 2008.

30- PRKNO A., WACKER C., BRUNKHORSTAND F.M and SCHLATTMANN P.: Procalcitonin-guided therapy in Intensive Care Unit patients with severe sepsis and septic shock-a systematic review and meta-analysis. Crit. Care, 17: R291, 2013.

31- NYLEN E., MULLER B., BECKER K.L. and SNIDER R.: The future diagnostic role of procalcitonin levels: The need for improved sensitivity. Clin. Infect Dis., 36: 8234, 2003. 


\section{قيمة مصل Pro-calcitonin فى تشخيص إلتهاب الصفاق الجرثومى العفوى والتنبؤ بالإستجابة للعلاج التهاب}

إلتهاب الصفاق الجرثومى العفوى (SBP) هو آحد المضاعفات القاتلة لتليف الكبد. يعتبر التشخيص المبكر والإدارة المناسبة آمراً بالغ

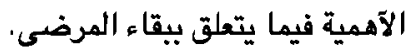

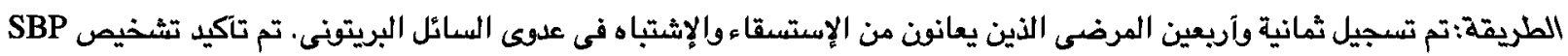

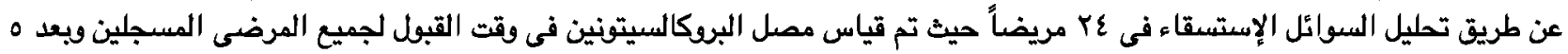

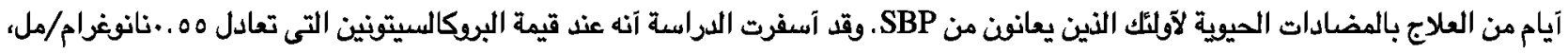

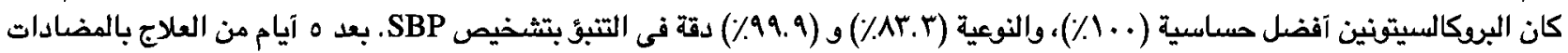



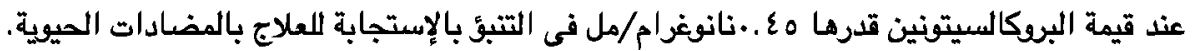
وقد إستخلصت الدراسة آنه قد يكون قياس البروكالسيتونين فى الدم إختبار غير تداخلى فى جسم المريض ويستخدم لتشخيص وتوجيه العلاج بالمضادات الحيوية لمرضى SBP. 